\title{
PENGARUH AGENCY COST TERHADAP NILAI PERUSAHAAN BUMN YANG TERDAFT AR DI BURSA EFEK INDONESIA
}

\author{
aMade Ratih Nurmalasari, bNi Wayan Merry Nirmala Yani \\ abUniversitas Pendidikan Nasional \\ ratihnurmalasari@undiknas.ac.id
}

Received: September $\quad$ Accepted : October 1 Published: December

\begin{abstract}
ABSTRAK
Agency problem timbul akibat adanya perbedaan kepentingan antara agen dan prinsipal. Kepemilikan saham pada perusahaan BUMN yang terkonsentrasi pada kepemilikan pemerintah sebagai prinsipal cenderung memungkinkan terjadinya agency problem yang lebih besar. Agency problem akan menimbulkan biaya yang harus ditanggung oleh perusahaan yang disebut agency cost. Pengukuran tingkat agency cost pada penelitian ini menggunakan expense ratio dan total turnover ratio. Penelitian ini bertujuan untuk melihat pengaruh agency cost terhadap nilai perusahaan BUMN yang diproksikan dengan rasio Tobin's Q.
\end{abstract}

Kata kunci: Agency problem, expense ratio, total asset turnover, rasio Tobin's $Q$

\section{ABSTRACT}

Agency problems arise due to differences in interests between the agent and the principal. Share ownership in state-owned companies that are kept in government ownership as principals tend to allow for greater agency problems. Agency problems will cause costs to be borne by the company called agency costs. The measurement of the level of agency costs in this study uses the ratio of costs and the ratio of total turnover. This study aims to see the effect of agency costs on the value of state-owned enterprises as proxied by the Tobin's $Q$ ratio.

Key words: Agency problem, expense ratio, total asset turnover, Tobin's Q ratio

\section{PENDAHULUAN}

Para pemegang saham pada suatu perusahaan berhak untuk memilih dewan komisaris yang kemudian akan memiliki para manajer untuk menjalankan operasional perusahaan. Para manajer, atau disebut agen, akan lebih banyak memiliki informasi mengenai perusahaan termasuk posisi keuangan dibandingkan pemerintah sebagai pemilik saham, atau disebut prinsipal, hal ini akan menimbulkan asimetri informasi. Masalah lain yang juga mungkin akan timbul adalah adanya perbedaan kepentingan antara agen dengan prinsipal yang menyebabkan terjadinya masalah agensi (agency problem), di mana agen bertindak tidak sesuai dengan kepentingan prinsipal atau pemegang saham (Sari, 2017). Agency problem menimbulkan biaya yang harus ditanggung oleh perusahaan sehingga menambah total beban operasional (Kahira et al., 2021). Berdasarkan penelitian yang dilakukan oleh Pandey \& Sahu (2020), peningkatan agency cost menyebabkan penurunan nilai perusahaan.

Untuk mengukur tingkat agency cost perusahaan dapat digunakan dua alternatif rasio efisiensi yang sering digunakan dalam literatur akuntansi dan literatur ekonomi keuangan yaitu expense ratio dan total asset turnover. Expense ratio mengukur biaya keagenan berdasarkan rasio beban operasi terhadap total penjualan. Semkain tinggi rasio ini makan semakin tinggi agency cost. Sedangkan total asset turnover mengukur biaya keagenan berdasarkan tingkat perputaran aktiva. Semakin tinggi rasio ini maka semakin produktif aktiva tersebut digunakan untuk menciptakan nilai bagi pemegang saham (Faizal, 2004). 
Peningkatan nilai bagi pemegang saham ditunjukkan dengan meningkatnya nilai perusahaan. Nilai perusahaan yang meningkat menunjukkan agency problem yang minim pada perusahaan. Nilai perusahaan salah satunya dapat diukur dari rasio Tobin's $Q$. Rasio Tobin' $Q$ paling baik digunakan untuk mengukur nilai perusahaan karena adanya agency problem akan berdampak pada harga saham dan jumlah saham beredar yang dijadikan dasar penghitungan rasio Tobin's Q (Wardani \& Susilowati, 2017). Unsur-unsur kewajiban pada seluruh aset perusahaan juga dimasukkan sebagai dasar penghitungan, termasuk kewajiban terhadap kreditur yang menjadi agent monitoring bagi manajemen perusahaan. Sehingga rasio ini dinilai bisa memberikan informasi paling baik dan bisa menjelaskan berbagai fenomena dalam kegiatan perusahaan (Sari, 2017).

Berdasarkan penelitian oleh Zaman \& Nurfahrudiyanto (2017), analisis sensitivitas yang signifikan pengaruhnya terhadap biaya keagenan adalah kepemilikan manajerial. Hal ini konsisten dengan penelitian Ang et al. (2000) dan Singh \& Davidson (2003) yang menyatakan semakin tinggi kepemilikan manajerial secara positif dan signifikan mempengaruhi efisiensi pemanfaatan aktiva perusahaan dan beban operasional pada perusahaan. Hal ini berarti bahwa semakin tinggi kepemilikan manajerial, agency cost akan semakin rendah karena manajer bertindak sebagai agen sekaligus prinsipal.

Di Indonesia, salah satu pilar ekonomi yang bertujuan untuk meningkatkan kesejahteraan rakyat adalah Badan Usaha Milik Negara (BUMN). Berdasarkan keterangan Erick Tohir selaku Menteri Badan Usaha Milik Negara, laba bersih untuk seluruh BUMN mengalami penurunan hampir $80 \%$ pada beberapa tahun terakhir (market.bisnis.com). Penurunan laba dapat terjadi karena lemahnya manajemen biaya termasuk agency cost, sehingga terjadi penurunan terhadap nilai perusahaan (Khuzaimah, 2020).

Berdasarkan Pasal 1 angka 1 Undang-Undang Nomor 19 Tahun 2003 tentang Badan Usaha Milik Negara, seluruh atau sebagian besar modal perusahaan BUMN melalui penyertaan langsung dimiliki oleh negara berasal dari kekayaan negara yang dipisahkan. Hal ini berarti bahwa kepemilikan saham BUMN cenderung terkonsentrasi yaitu suatu kondisi dimana sebagian besar saham di kendalikan oleh suatu kelompok atau individu yang memiliki saham relatif dominan dari yang lainnya (Dallas, 2004). Penelitian yang dilakukan oleh Li et al. (2021) terhadap perusahaan BUMN di Cina yang sebagian besar kepemilikan sahamnya terkonsentrasi, menunjukkan rendahnya agency cost perusahaan.

Peneliti tertarik untuk mengetahui pengaruh agency cost terhadap nilai perusahaan BUMN yang terdaftar pada Bursa Efek Indonesia pada periode tahun 2015 hingga 2019. Secara teoritis, penelitian ini diharapkan mampu memberikan kontribusi dalam pengembangan teori agency problem, khususnya pada perusahaan BUMN. Dalam hal praktis, hasil penelitian diharapkan akan memberikan sumbangan masukan terkait hal-hal yang dapat menyebabkan turunnya nilai perusahaan BUMN sehingga dapat dilakukan kegiatan preventif seperti peningkatan pengawasan.

\section{KAJIAN LITERATUR}

Menurut Brigham \& Daves (2007), agency problem muncul akibat adanya perbedaan kepentingan antara agen dan principal Pengawasan terhadap terjadinya agency problem dapat menimbulkan biaya yang harus ditanggung oleh perusahaan yang disebut biaya keagenan (agency cost). Menurut Jensen \& Meckling (1976), agency cost terdiri atas:

1) Bonding Cost; yaitu biaya yang timbul untuk menjamin bahwa agen tidak akan melakukan tindakan yang akan merugikan perusahaan. Contohnya penyelenggaraan sistem akuntansi.

2) Monitoring Cost; yaitu biaya yang timbul untuk mengawasi aktivitas dan perilaku manajer. Contohnya membayar auditor untuk mengaudit laporan keuangan perusahaan.

3) Residual Loss; yaitu biaya yang timbul akibat adanya perbedaan keputusan yang diambil oleh manajer dengan keputusan yang seharusnya memberikan manfaat 
maksimal pada pemegang saham. Contohnya pemanfaatan fasilitas perusahaan secara berlebihan oleh agen.

Biaya keagenan (agency cost) yang ditanggung oleh perusahaan akan merugikan perusahaan karena akan berdampak pada nilai perusahaan tersebut. Semakin tinggi agency cost, nilai perusahaan akan semakin menurun. Berdasarkan hasil penelitian Manalu \& Natalie (2015), agency cost yang secara simultan berpengaruh signifikan terhadap nilai perusahaan. Hasil yang sama juga didapatkan dari hasil penelitian oleh Muchlas \& Alamsyah (2017).

Untuk mengukur tingkat agency cost perusahaan dapat digunakan dua alternatif rasio efisiensi yang sering digunakan dalam literatur akuntansi dan literatur ekonomi keuangan yaitu expense ratio dan total asset turnover. Expense ratio mengukur biaya keagenan berdasarkan rasio beban operasi terhadap total penjualan. Beban operasi merefleksikan diskresi manajerial dalam membelanjakan sumberdaya perusahaan. Semakin tinggi beban diskresi manajerial maka semakin tinggi biaya keagenan yang terjadi (Faisal, 2005). Expense ratio dihitung dengan cara total beban operasional investasi dibagi dengan rata-rata asset investasi atau Nilai Aktiva Bersih (NAB). Total asset turnover mengukur biaya keagenan berdasarkan tingkat perputaran aktiva. Tingkat perputaran aktiva merupakan rasio antara total penjualan dengan total aktiva. Rasio ini digunakan untuk mengukur efisiensi penggunaan aktiva oleh manajemen. Semakin tinggi rasio ini maka semakin produktif aktiva tersebut digunakan untuk menciptakan nilai bagi pemegang saham (Faisal, 2005).

Berdasarkan penelitian oleh Xiao \& Zhao (2009), expense ratio berpengaruh negatif terhadap kinerja keuangan perusahaan. Begitu pula dengan hasil penelitian oleh Komarudin \& Affandi (2019) dan Layyinaturrobaniyah et al. (2014) yang memperoleh hasil expense ratio berpengaruh negatif signifikan terhadap nilai perusahaan. Hal ini berarti bahwa semakin tinggi expense ratio maka nilai perusahaan akan semakin menurun, begitu sebaliknya. Penelitian oleh Layyinaturrobaniyah et al. (2014) juga memperoleh hasil bahwa Total asset turnover berpengaruh positif terhadap kinerja perusahaan, walaupun hal ini diperlemah oleh kepemilikan manajerial. Singh \& Davidson (2003) juga memperoleh hasil bahwa total aset berpengaruh positif terhadap nilai perusahaan. Hal ini berarti bahwa semakin tinggi perputaran aset total, biaya agensi semakin rendah, maka nilai perusahaan akan semakin tinggi, begitupun sebaliknya.

Dari uraian penelitian terdahulu dan berbagai teori, maka dirumuskan hipotesis sebagai berikut:

$\mathrm{H} 1$ : Expense ratio berpengaruh negatif signifikan terhadap nilai perusahaan BUMN yang terdaftar di Bursa Efek Indonesia

H2: Total asset turnover berpengaruh positif signifikan terhadap nilai perusahaan BUMNyang terdaftar di Bursa Efek Indonesia

\section{METODE}

Penelitian ini menggunakan pendekatan kuantitatif dengan metode purposive sampling. Data dalam penelitian ini adalah laporan keuangan dari 24 perusahaan BUMN di Indonesia selama periode pengamatan yaitu dari tahun 2015 hingga 2019 yang terdaftar pada Bursa Efek Indonesia. Terdapat 25 perusahaan BUMN yang terdaftar di Bursa Efek Indonesia, namun perusahaan PT Indofarma, Tbk, (INAF) tidak dimasukkan sebagai data penelitian karena harga saham selama periode penelitian terlalu berfluktuasi yang mengakibatkan tidak Iulus uji normalitas. Berikut adalah daftar perusahaan BUMN Indonesia yang diteliti.

Tabel 1

Daftar Perusahaan BUMN yang Diteliti

\begin{tabular}{|c|c|c|}
\hline Nomor & Nama Perusahaan & Kode BEI \\
\hline 1 & PT Adhi Karya (Persero) Tbk. & ADHI \\
\hline 2 & PT Bank BNI (Persero) Tbk. & BBNI \\
\hline 3 & PT Bank BRI (Persero) Tbk. & BBRI \\
\hline
\end{tabular}




\begin{tabular}{|c|c|c|}
\hline 4 & PT Bank Tabungan Negara (Persero) Tbk. & BBTN \\
\hline 5 & PT Bank Pembangunan Daerah Jawa Barat dan Banten Tbk. & BJBR \\
\hline 6 & PT PP (Persero) Tbk. & PTPP \\
\hline 7 & PT Bank Mandiri (Persero) Tbk. & BMRI \\
\hline 8 & PT Krakatau Steel (Persero) Tbk. & KRAS \\
\hline 9 & PT Garuda Indonesia (Persero) Tbk. & GIAA \\
\hline 10 & PT Jasa Marga (Persero) Tbk. & JSMR \\
\hline 11 & PT Gas Negara Tbk. & PGAS \\
\hline 12 & PT Semen Baturaja (Persero) Tbk. & SMBR \\
\hline 13 & PT Timah Tbk. & TINS \\
\hline 14 & PT Telekomunikasi Indonesia (Persero) Tbk. & TLKM \\
\hline 15 & PT Wijaya Karya (Persero) Tbk. & WIKA \\
\hline 16 & PT Waskita Beton Precast Tbk. & WSBP \\
\hline 17 & PT Waskita Karya (Persero) Tbk. & WSKT \\
\hline 18 & PT Betonjaya Manunggal Tbk. & WTON \\
\hline 19 & PT Elnusa Tbk. & ELSA \\
\hline 20 & PT Kimia Farma (Persero) Tbk. & KAEF \\
\hline 21 & PT Semen Indonesia (Persero) Tbk. & SMGR \\
\hline 22 & PT PP Properti Tbk. & PPRO \\
\hline 23 & PT Bukit Asam Tbk. & PTBA \\
\hline 24 & PT Aneka Tambang Tbk. & ANTM \\
\hline
\end{tabular}

Sumber: Bursa Efek Indonesia

Variabel-variabel yang digunakan dalam penelitian ini adalah sebagai berikut:

1) Variabel dependen atau variabel terikat dalam penelitian ini adalah nilai perusahaan (Tobin's Q). Variabel ini menggunakan satuan rasio dan dihitung dengan menggunakan rumus sebagai berikut.

Tobins $Q=\frac{(\text { harga saham pasar })(\text { jumlah saham beredar })+\text { nilai buku total hutang }}{\text { nilai buku total aktiva }}$

2) Variabel independen atau variabel bebas dalam penelitian ini adalah expense ratio dan total asset turnover. Adapun pengukurannya adalah sebagai berikut.

$$
\begin{gathered}
\text { Expense Ratio }=\frac{\text { total beban operasional }}{\text { pendapatan bersih }} \\
\text { Total Asset Turnover }=\frac{\text { pendapatan bersih }}{\text { nilai buku total aktiva }}
\end{gathered}
$$

HASIL DAN PEMBAHASAN

Berikut disajikan hasil uji sebagai berikut.

Tabel 2

Hasil Uji Normalitas

\begin{tabular}{|l|l|r|}
\hline \multicolumn{2}{|c|}{ One-Sample Kolmogorov-Smirnov Test } \\
\hline N & \multicolumn{2}{|c|}{ Unstandardized Residual } \\
\hline Normal Parameters ${ }^{\text {a,b }}$ & Mean & .0000000 \\
\cline { 2 - 4 } & $\begin{array}{l}\text { Std. } \\
\text { Deviation }\end{array}$ & .68469072 \\
\hline \multirow{2}{*}{$\begin{array}{l}\text { Most Extreme } \\
\text { Differences }\end{array}$} & Absolute & .161 \\
\cline { 2 - 4 } & Positive & .161 \\
\cline { 2 - 4 } & Negative & -.120 \\
\hline
\end{tabular}




\begin{tabular}{|l|r|}
\hline Test Statistic & .161 \\
\hline Asymp. Sig. (2-tailed) & $.111^{\mathrm{c}}$ \\
\hline
\end{tabular}

Uji normalitas dilakukan untuk melihat apakah residual mengikuti distribusi normal atau tidak (Lupiyoadi \& Ikhsan, 2015:134). Pengujian asumsi normalitas dapat dilakukan dengan melakukan uji Kolmogorof Smirnov, dengan bantuan IBM SPSS Statistic 25. Berdasarkan Tabel 2 diperoleh nilai Asymp. Sig. (2-tailed) sebesar 0,111 yang dimana nilainya lebih besar dari alpha yang digunakan yaitu $(0,05)$. Dengan demikian dapat disimpulkan bahwa residual dari model regresi berganda memenuhi asumsi distribusi normal.

Tabel 3

Hasil Uji Autokorelasi/Uji Independen Durbin Watson

\begin{tabular}{ll|r|r|r|rr}
\multicolumn{1}{c|}{} & \multicolumn{5}{c}{ Model Summary } \\
Model & $\mathrm{R}$ & R Square & $\begin{array}{c}\text { Adjusted R } \\
\text { Square }\end{array}$ & $\begin{array}{c}\text { Std. Error of } \\
\text { the Estimate }\end{array}$ & \multicolumn{2}{|c}{ Durbin-Watson } \\
\hline 1 & $.388^{\mathrm{a}}$ & .151 & .070 & .7165537 & 1.887
\end{tabular}

a. Predictors: (Constant), ER, AT

b. Dependent Variable: TOBIN

Uji asumsi independen dilakukan untuk mengetahui apakah terdapat korelasi pada residual (Lupiyoadi \& Ikhsan, 2015, 146). Asumsi residual independen dapat dilakukan dengan menggunakan uji $d$ Durbin-Watson, dengan bantuan IBM SPSS Statistic 25.

Diperoleh nilai $d$ Durbin-Watson sebesar 1,887. Selanjutnya nilai $d$ Durbin-Watson tersebut akan dibandingkan dengan nilai tabel signifikasi $\alpha=5 \%$, dengan jumlah sampel sebanyak $24(\mathrm{~T}=24)$, satu variabel dependen dan dua variabel independen $(\mathrm{k}=3)$. Dari tabel $d$ Durbin-Watson dengan $\alpha=5 \%, \mathrm{~T}=24$, dan $\mathrm{k}=3$ diperoleh nilai $d_{L}$ dan $d_{U}$ secara berturutturut yaitu 1,101 dan 1,656 dengan:

$$
\begin{gathered}
4-d_{L}=4-1,656=2,899 \\
\text { dan } \\
4-d_{U}=4-1,101=2,344 .
\end{gathered}
$$

Karena nilai dari $d$ Durbin-Watson terletak di antara nilai $d_{U}$ dan $4-d_{L}$ maka mengindikasikan bahwa tidak terdapat autokorelasi positif ataupun negatif pada residual.

\begin{tabular}{|c|c|c|c|c|c|c|c|}
\hline \multirow[b]{3}{*}{ Model } & \multicolumn{5}{|c|}{ Coefficients ${ }^{a}$} & & \\
\hline & \multicolumn{2}{|c|}{$\begin{array}{c}\text { Unstandardized } \\
\text { Coefficients }\end{array}$} & $\begin{array}{l}\text { Standardi } \\
\text { zed } \\
\text { Coefficien } \\
\text { ts }\end{array}$ & \multirow[b]{2}{*}{$\mathrm{t}$} & \multirow[b]{2}{*}{ Sig. } & \multicolumn{2}{|c|}{ Collinearity Statistics } \\
\hline & B & Std. Error & & & & $\begin{array}{l}\text { Ioleran } \\
\text { ce }\end{array}$ & VIF \\
\hline 1 (Constant) & 1.905 & .352 & & 5.404 & .000 & & \\
\hline AT & .001 & .006 & .049 & .187 & .854 & .595 & 1.681 \\
\hline ER & -.555 & .347 & -.417 & -1.600 & .124 & .595 & 1.681 \\
\hline
\end{tabular}

\section{Tabel 4 \\ Hasil Uji Multikolinieritas dengan Melihat Nilai Tolerance dan VIF SPSS}


a. Dependent Variable: TOBIN

Tujuan melakukan uji multikolinearitas dalam penelitian adalah untuk menguji apakah dalam model regresi mengandung korelasi (hubungan kuat) antar variabel bebas maupun variabel independen. Model regresi yang baik seharusnya tidak terjadi korelasi di antara variabel bebas atau tidak terjadi gejala multikolinearitas (Lupiyoadi \& Ikhsan, 2015, 141). Untuk mendeteksi ada tidaknya gejala multikolinearitas dalam model regresi, maka dapat dilakukan dengan melihat nilai tolerance dan variance inflating factor (VIF), dengan bantuan IBM SPSS Statistic 25.

Berdasarkan tabel 4, "Coefficients" pada bagian "Collinearity Statistics" diketahui nilai Tolerance untuk variabel Asset Turnover (AT) dan Expense Ratio (ER) adalah 0,595 lebih besar dari 0,10. Sementara, nilai VIF untuk variabel Asset Turnover (AT) dan Expense Ratio (ER) yaitu sebesar 1,681<10,00. Maka mengacu pada dasar pengambilan keputusan dalam uji multikolinearitas dapat disimpulkan bahwa tidak terjadi gejala multikolineritas dalam model regresi.

\section{Gambar 1}

Hasil Uji Heteroskedastisitas

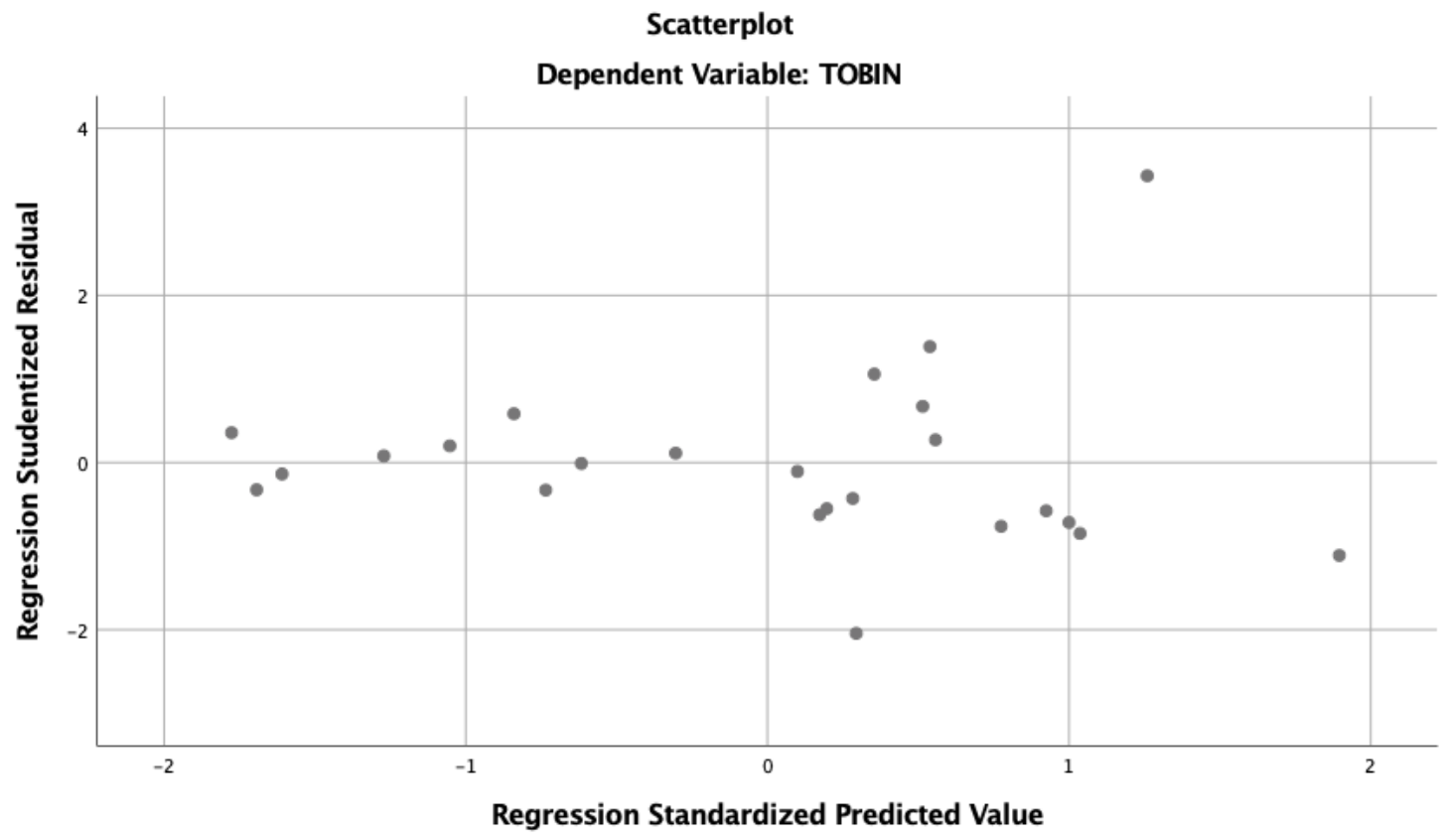

Dari gambar 1, tampak bahwa tidak terdapat pola tertentu yang jelas, di mana titik-titik menyebar di atas 0 sumbu $Y$ dan juga di bawah secara merata. Hasil ini menunjukkan bahwa model mengalami homoskedastisitas dan dinyatakan memenuhi uji asumsi klasik. Dengan demikian dapat disimpulkan bahwa residual dari model regresi berganda memenuhi asumsi asumsi klasik.

\section{Tabel 5 \\ Hasil Uji Regresi \\ Model Summary}

R 


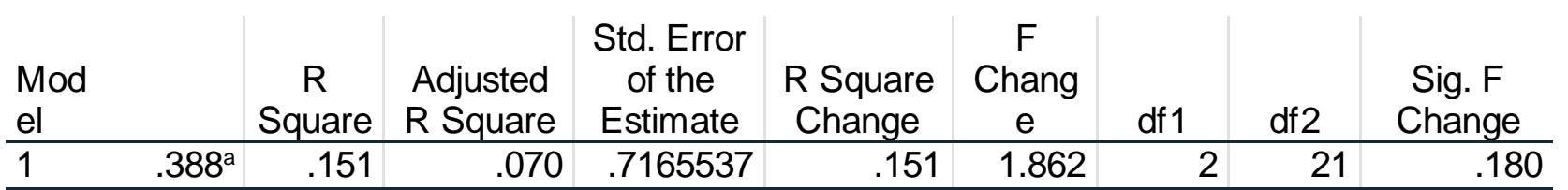

a. Predictors: (Constant), ER, AT

b. Dependent Variable: TOBIN

\begin{tabular}{|c|c|c|c|c|c|c|}
\hline \multirow[b]{2}{*}{ Model } & \multicolumn{6}{|c|}{ ANOVA $^{a}$} \\
\hline & & $\begin{array}{l}\text { Sum of } \\
\text { Squares }\end{array}$ & df & $\begin{array}{l}\text { Mean } \\
\text { Square }\end{array}$ & $\mathrm{F}$ & Sig. \\
\hline \multirow[t]{3}{*}{1} & Regression & 1.912 & 2 & .956 & 1.862 & $.180^{\mathrm{b}}$ \\
\hline & Residual & 10.782 & 21 & .513 & & \\
\hline & Total & 12.694 & 23 & & & \\
\hline
\end{tabular}

a. Dependent Variable: TOBIN

b. Predictors: (Constant), ER, AT

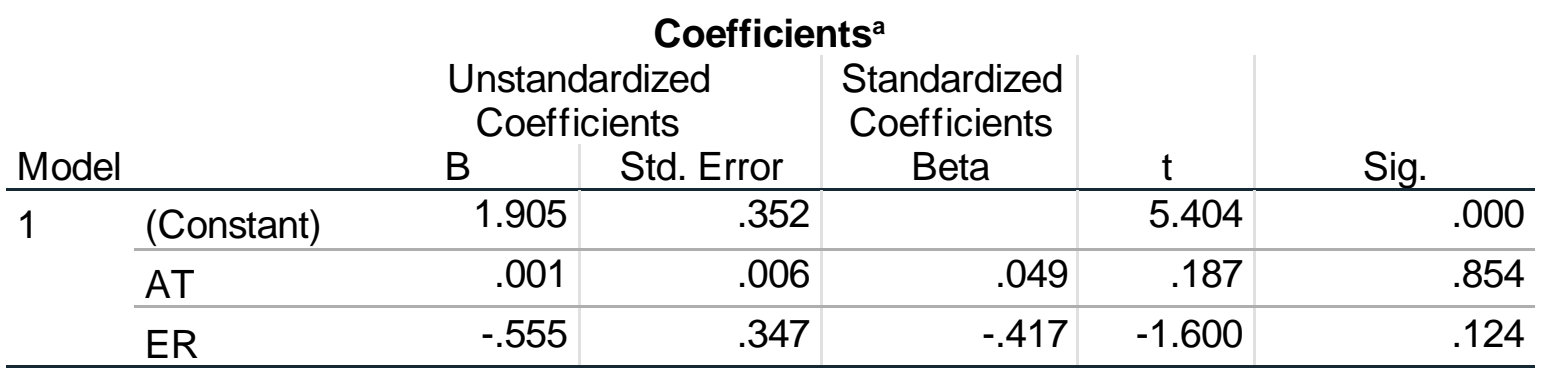

a. Dependent Variable: TOBIN

\begin{tabular}{lr|r|r|r|r}
\multicolumn{7}{c}{ Residuals Statistics } & & \\
& Minimum & Maximum & \multicolumn{1}{c}{ Mean } & \multicolumn{1}{c}{$\begin{array}{l}\text { Std. } \\
\text { Deviation }\end{array}$} & N \\
\hline Predicted Value & .807072 & 1.865730 & 1.319207 & .2882971 & 24 \\
\hline Std. Predicted Value & -1.776 & 1.896 & .000 & 1.000 & 24 \\
\hline $\begin{array}{l}\text { Standard Error of } \\
\text { Predicted Value }\end{array}$ & .152 & .384 & .245 & .067 & 24 \\
\hline $\begin{array}{l}\text { Adjusted Predicted } \\
\text { Value }\end{array}$ & .749309 & 2.126595 & 1.347309 & .3366481 & 24 \\
\hline Residual & -1.2365410 & 2.3160274 & .0000000 & .6846907 & 24 \\
\hline Std. Residual & -1.726 & 3.232 & .000 & .956 & 24 \\
\hline Stud. Residual & -2.044 & 3.431 & -.018 & 1.033 & 24 \\
\hline Deleted Residual & -1.7341516 & 2.6098757 & -.0281023 & .8038856 & 24 \\
\hline Stud. Deleted Residual & -2.228 & 5.051 & .045 & 1.303 & 24 \\
\hline Mahal. Distance & .080 & 5.641 & 1.917 & 1.602 & 24 \\
\hline Cook's Distance & .000 & .560 & .061 & .148 & 24 \\
\hline $\begin{array}{l}\text { Centered Leverage } \\
\text { Value }\end{array}$ & .003 & .245 & .083 & .070 & 24 \\
\hline
\end{tabular}

a. Dependent Variable: TOBIN

Selanjutkan dilakukan uji signifikasi parameter regresi berganda serentak dengan uji $F$ dengan hipotesis sebagai berikut:

$H_{0}$ : seluruh variabel independen baik variable asset turnover dan expense ratio tidak berpengaruh siginifikan terhadap nilai perusahaan (Tobin's $Q$ ) 
$H_{1}$ : minimal terdapat satu variabel independen baik variabel asset turnover atau expense ratio berpengaruh siginifikan terhadap nilai perusahaan (Tobin's $Q$ )

Dengan taraf nyata $\alpha=5 \%$ diperoleh kesimpulan bahwa nilai sig $\geq \alpha$ yaitu $0,180 \geq$ 0,05 maka terima $H_{0}$ yang mengindikasikan bahwa seluruh variabel independen baik variabel asset turnover dan expense ratio tidak berpengaruh siginifikan terhadap Nilai Perusahaan (Tobin's Q). Selanjutnya untuk lebih memastikannya lagi maka dilakukan uji parameter secara parsial (secara individu) dengan uji $t$, dengan hipotesis sebagai berikut:

Untuk asset turnover:

$H_{0}$ : variabel asset turnover tidak berpengaruh siginifikan terhadap nilai perusahaan (Tobin's Q)

$H_{1}$ : variabel asset turnover berpengaruh siginifikan terhadap nilai perusahaan (Tobin's Q) Untuk expense ratio:

$H_{0}$ : variabel expense ratio tidak berpengaruh siginifikan terhadap nilai perusahaan (Tobin's Q) $H_{1}$ : variabel expense ratio berpengaruh siginifikan terhadap nilai perusahaan (Tobin's Q)

Berdasarkan tabel, diperoleh nilai sig dari Asset Turnover (AT) dan Expense Ratio (ER) secara berturut-turut sebesar 0,854 dan 0,124 ; di mana nilai tersebut lebih besar dari 0,05 sehingga menyebabkan terima $H_{0}$ yang mengindikasikan kesimpulan secara berturutturut bahwa variabel asset turnover tidak berpengaruh siginifikan terhadap nilai perusahaan (Tobin's Q) dan variabel expense ratio tidak berpengaruh siginifikan terhadap nilai perusahaan (Tobin's Q). Dapat disimpulkan bahwa tidak ada pengaruh yang signifikan antara agency cost yang diukur dari dua alternatif rasio efisiensi terhadap nilai perusahaan BUMN yang terdaftar di Bursa Efek Indonesia pada periode tahun 2015 hingga 2019. Hal ini dapat terjadi karena terdapat struktur kepemilikan manajerial pada saham perusahaan BUMN yang terdaftar di Bursa Efek Indonesia. Kepemilikan manajerial adalah struktur kepemilikan pihak insider yaitu pemegang saham yang berada di jajaran eksekutif dan direktur (manajemen) (Dewi \& Ardiana, 2014). Kemungkinan terjadinya agency problem pada perusahaanperusahaan ini akan semakin sedikit karena prinsipal juga tertindak sebagai agen sehingga memiliki satu tujuan utama yaitu memaksimalkan nilai perusahaan.

Pada tabel juga dapat dilihat bahwa nilai $R$-square sebesar $0,151 \mathrm{Hal}$ ini dapat diinterpretasikan bahwa sebesar $15,1 \%$ variabilitas nilai perusahaan (Tobin's Q) dijelaskan oleh variabel independen baik variabel asset turnover dan expense ratio, sedangkan $84,9 \%$ variabel nilai perusahaan (Tobin's $Q$ ) dijelaskan oleh variabel di luar model. Hal ini berarti ada variabel lain di luar agency costyang diukur dari dua alternatif rasio efisiensi pada perusahaan BUMN yang terdaftar di Bursa Efek Indonesia pada periode tahun 2015 hingga 2019 yang lebih memberikan pengaruh yang signifikan terhadap nilai perusahaan.

\section{SIMPULAN}

Simpulan yang diperoleh dari hasil penelitian yang telah diuraikan sebelumnya, yaitu expense ratio tidak berpengaruh signifikan terhadap nilai perusahaan BUMN yang terdaf tar di Bursa Efek Indonesia dan asset turnover tidak berpengaruh signifikan terhadap nilai perusahaan BUMN yang terdaftar di Bursa Efek Indonesia. Dapat disimpulkan bahwa agency cost pada perusahaan BUMN yang terdaftar di Bursa Efek Indonesia tidak berpengaruh signifikan terhadap nilai perusahaan. Hal ini bisa terjadi karena terdapat struktur kepemilikan manajerial pada saham perusahaan BUMN yang terdaftar di Bursa Efek Indonesia, sehingga semakin sedikit kemungkinan terjadinya agency problem pada perusahaan-perusahaan ini karena prinsipal juga tertindak sebagai agen dan memiliki satu tujuan utama yaitu memaksimalkan nilai perusahaan.

Mengingat bahwa kepemilikan manajerial pada perusahaan BUMN dapat mempengaruhi agency cost, maka penelitian ini menyarankan agar selanjutnya dapat diteliti mengenai pengaruh semakin tingginya presentase kepemilikan manajerial pada perusahaan BUMN terhadap semakin terkontrolnya agency problem pada perusahaan tersebut. Bagi perusahaan khususnya BUMN yang ingin memaksimalkan nilai perusahaan sebaiknya tidak 
hanya berfokus pada penurunan agency cost, tetapi juga memperhatikan beberapa faktor lainnya seperti profitabilitas perusahaan dan struktur kepemilikan saham.

\section{REFERENSI}

Ang, J. S., Cole, R. A., dan Lin., J.W. 2000. Agency Cost and Ownership Structure. Journal of Finance. 55(1): 377-397.

Brigham, Eugene F., \& Philip R. Daves. 2007. Intermediate Financial Management, $12^{\text {th }}$ edition. USA: Thomson Higher Education.

Dallas, George. 2004. Governance and Risk Analytical Hand Books for Investors, Managers, Directors and Stakeholders. New York: McGraw Hill.

Dewi, Ni Luh Gede Emy Lestari \& Putu Agus Ardiana. 2014. Pengaruh Kepemilikan Manajerial pada Agency Cost Perusahaan Manufaktur yang Terdaftar di Bursa Efek Indonesia Tahun 2008-2012. E-Jurnal Akuntansi Universitas Udayana. 9(1): 245-258.

Faizal, 2004. Analisis Agency Costs, Struktur Kepemilikan dan Mekanisme Corporate Governance. Bali: Simposium Nasional Akuntansi VII.

Jensen, Michael C. \& Meckling. William H.. 1976. Theory of The Firm: Managerial Behavior, Agency Cost, and Ownership Structure. Jurnal of Financial Economics. 3(4): 305-360.

Kahira, Aminatul, Desi llona, \& Hilda Mary. 2021. Family Control, Biaya Keagenan, dan Risiko Keuangan Terhadap Nilai Perusahaan. Akuntansi Dewantara Jurnal. 5(1): 11-18.

Khuzaimah, Avitia Mega. 2020. Pengaruh Kualitas Laba Dan Profitabilitas Terhadap Nilai Perusahaan. Tesis, Universitas Airlangga.

Komarudin, Mamay \& Naufal Affandi. 2019. Free Cash Flow Kinerja Keuangan dan Agency Cost pada Perusahaan Perdagangan yang Terdaftar di Bursa Efek Indonesia. Jurnal Equilibrium. 8(2): 10-19.

Layyinaturrobaniyah, Rachmat Sudarsono, \& Desi Fitriani. 2014. Agency Cost pada Perusahaan Keluarga dan Non Keluarga. Jurnal Siasat Bisnis. 18(2): 169-179.

Manalu, Sahala \& Sheren Natalie. 2015. Pengaruh Agency Cost terhadap Kinerja Keuangan Perusahaan Keluarga Menggunakan Tobin's Q \& Altman Z-Score. Jurnal Modernisasi. 11(3): 147-160.

Muchlas, Zainul \& Alamsyah. 2017. Pengaruh Agency Cost terhadap Kinerja Keuangan Perusahaan Keluarga Menggunakan Tobin's Q \& Altman Z-Score. Jurnal JIBEKA. 11(1): 92-98.

Li, Songsong, Daquan Gao, \& Xiaofeng Hui. 2021. Corporate Governance, Agency Costs, and Corporate Sustainable Development: A Mediating Effect Analysis. Discrete Dynamics in Nature and Society. 4(1): 1-15.

Lupiyoadi, Rambat \& Ridho Bramulya Ikhsan. 2015. Praktikum Metode Riset Bisnis. Jakarta: Salemba Empat.

Pandey, Krishna Dayal \& Tarak Nath Sahu. 2020. Debt Financing, Agency Cost and Firm Performance: Evidence from India. SAGE Journals. 23(3): 267-274.

Sari, Silvia Waning Hiyun Puspita. 2016. Analisis Simultan Sktruktur Kepemilikan, leverage, dan Kebijakan Dividen Sebagai Mekanisme Kontrol Agency Problem. Tesis. Program Magister Manajemen Universitas Gadjah Mada, Jogyakarta.

Singh, Manohar \& Wallace N. Davidson. 2003. Agency Costs, Ownership Structure and Corporate Governance Mechanisms. Journal of Banking \& Finance. 27(1): 793-816.

Undang-undang Republik Indonesia No. 19 Tahun 2003 tentang Badan Usaha Milik Negara. Pemerintah Republik Indonesia.

Wardani, Dewi Kusuma \& Wahyu Tri Susilowati. 2017. Pengaruh Agency Cost terhadap Nilai Perusahaan dengan Transparansi Informasi sebagai Variabel Moderasi. Jurnal Akuntasi Universitas Kristen Maranatha. 12(1): 1-12.

Xiao, S., \& S. Zhao. (2009). How Do Agency Costs Affect Firm Value? Evidence from China. Journal of Economic Literature. 1(1): 1-10.

Zaman, Badrus \& Aan Nurfahrudiyanto. 2017. Mekanisme Internal Corporate Governance Pengaruhnya terhadap Agency Cost (Studi pada Perusahaan Manufaktur di BEl). Nusantara of Research. 1(1): 51-59. 
https://market.bisnis.com/read/20210603/192/1400936/erick-thohir-laba-bumnanilok-jadi-rp28-triliun-pada-2020 